УДК 342.25

DOI https://doi.org/10.32837/pyuv.v0i5(34).644

B. P. Hecmop

orcid.org/0000-0002-8194-1392

кандидат юридичних наук

\title{
СТОЛИЧНЕ САМОВРЯДУВАННЯ У СПОЛУЧЕНОМУ КОРОЛІВСТВІ ВЕЛИКОБРИТАНІЇ І ПІВНІЧНОЇ ІРЛАНДІЇ
}

Місцеве самоврядування на сучасному етапі розвитку державності в Україні активно реформується. Не є виключенням і міське самоврядування. Особливу увагу теоретиків та практиків традиційно привертає самоврядування в столиці, і ця ситуація не є типовою лише для національної науки конституційного права. Адже, як правило, самоврядування в столиці більш чи менш істотно відрізняється від самоврядування в інших містах країни.

У зв'язку з цим важливим практичним завданням $є$ подальше вдосконалення столичного самоврядування в Україні, а важливим теоретичним завданням - належне доктринальне забезпечення цього процесу, в тому числі шляхом вивчення відповідного зарубіжного досвіду та формулювання висновків і пропозицій із запозичення цікавих підходів до організації столичного самоврядування.

Стан дослідженості столичного самоврядування в українській юридичній літературі слід визнати задовільним. $€$ монографічні дослідження з цього питання, є статті провідних фахівців з муніципального права, присвячені самоврядуванню в місті Київ (О. Батанова, В. Федоренка, I. Магновського, інших). Щодо дослідженості самоуправління в Лондоні, то виключення становлять лише окремі напрацювання В. Нестеровича, Н. Мішиної [1-6].

Метою статті є огляд столичного самоврядування в Лондоні, а також формулювання висновків та пропозицій на підставі проведеного дослідження.

Як уже було згадано вище, Лондон (Великий Лондон, Greater London) вважається окремим регіоном. Це єдиний регіон Англії, який має свій індивідуальний адміністративно-територіальний поділ.

Мешканці Лондона обирають свого мера одноособовий представницький орган (посадову особу), а також Асамблею Лондона - колегіальний представницький орган. Слід звернути увагу на назву - «Асамблея», а не «рада». В юридичній літературі часто висловлюється думка, що така назва споріднює цей представницький орган не з органами муніципального управління, а з парламентами історичних частин Сполученого Королівства - Асамблеєю Уельсу, Асамблеєю Північної Ірландіі. Така паралель $€$ вагомою, і навряд чи можна говорити про випадковий збіг назв. А тому доречно запропонувати, аналізуючи міське самоврядування, не аналізувати місцеве самоврядування в столицях як України, так і Сполученого Королівства. Ще одним аргументом на користь цього $€$ те, що в аналізованих країнах місцеве самоврядування в столицях регламентується окремими нормативно-правовими актами - в Україні це Закон України від 15 січня 1999 року «Про столицю України - місто-герой Київ», у Сполученому Королівстві - Акт про органи муніципального управління Великого Лондона 1999 року (Greater London Authority Act 1999).

Великий Лондон у цілому (як один із дев'яти регіонів Англіі) має такі органи місцевого самоврядування: Асамблея Лондона (представницький колегіальний орган, що складається 325 -ти членів) та мер (обирається населенням). Про назву «Асамблея» вже йшлося вище, а зараз варто наголосити, що до 2000 року замість Асамблеї функціонувала Рада Лондону. Компетенційною особливістю, яка відрізняє Асамблею від муніципальних рад (включаючи колишню Раду Лондона), є те, що вона не опікується питаннями охорони здоров'я. Відповідні повноваження зберігаються за державою - у Лондоні діє спеціальний, столичний підрозділ Національної служби охорони здоров'я (National Health Service London). Аналізуючи цю сукупність фактів, Д.О. Сжевський резюмує, що «в управлінні столицею Великобританії сталася великомасштабна децентралізація влади: більшість основних повноважень були передані вперше заснованому меру лондонського мегаполісу» [7, с. 21]. Слід погодитися з цим висновком.

У кожній із 33-х адміністративно-територіальних одиниць столиці Сполученого Королівства у Сіті Лондон та у 32 -х лондонських бургах також функціонують муніципальні органи.

Кожен з лондонських бургів має свою раду та мера (ця посадова особа в деяких бургах обирається муніципальною радою бурга, а в деяких бургах - населенням), а також виконавчий орган.

Сіті Лондон здійснюе муніципальне управління зі збереженням традицій, до числа муніципальних органів належить Корпорація Сіті Лондон (обирається мешканцями та представниками бізнесу), Лорд-мер, два шерифи, Головний клерк, фрімени, суд олдерменів та інші церемоніальні органи та посадові особи. Дослідження структури та компетенції цих органів представляє здебільшого історичний інтерес. 
Н.С. Перфільєва погоджується з тим, що «особливий статус Лондона визначається передусім наявністю Лондонського Сіті, офіційно оголошеного «історичною аномалією» ще в рішеннях Королівської комісії 1837 р. Лондонський Сіті являє собою частину міської території, де ніхто не проживає, однак розташовані офіси найбільших світових банків й інших компаній, самоврядування в даному утворенні здійснюється особливим органом, існуючим вже більше 500 років, - Корпорацією Лондонського Сіті. Крім звичайних функцій лондонських районних рад, до числа специфічних видів діяльності Корпорації Лондонського Сіті відноситься таке, що історично склалося, виконання функцій посередника 3 урегулювання суперечок між компаніями, розташованими в Сіті» [8, с. 5]. Навряд чи можна погодитися із твердженням автора про те, що «Лондонський Сіті являє собою частину міської території, де ніхто не проживає» . Сіті не має щільної заселеності, але на станом на 1 січня 2016 року там проживало приблизно 8800 осіб, а працювало 317600 осіб (здебільшого у сфері фінансових, юридичних, страхових послуг) [9].

Цікавим є той факт, що коріння муніципального управління Сіті Лондон та гарантії його незалежності закладено в шостій поправці до Великої Хартії вольностей 1215 року (Magna Carta). Зрозуміло, що наявні й більш сучасні документи щодо муніципального управління Сіті, наприклад, Акт про вибори муніципальних органів Сіті Лондон 2002 року (City of London (Ward Elections) Act 2002) [10].

Сіті поділяється на 25 вардів (Wards of the City of London), кожен з яких обирає одного олдермена та кілька членів Корпорації Сіті - у залежності від кількості виборців від 2 до 10 членів, усього до складу Корпорації Сіті входить 100 членів.

Варто зауважити, що більшість країн на сучасній політичній карті світу роблять вибір на користь того, щоб місцеве самоврядування в столиці було б індивідуалізованим. Воно відрізняється від місцевого самоврядування в інших містах інколи дуже істотно, інколи - лише поодинокими рисами.

Наприклад, у ФРН місцеве самоврядування в місті Берлін організовано з урахуванням того, Берлін є містом - землею (тобто містом - суб'єктом федерації). Іншими словами, у формуванні підходів до організації місцевого (комунального) самоврядування було взято до уваги столичний статус Берліну. Однак можна стверджувати, що відмінностей в організації комунального управління Берліну не дуже багато. Дійсно, під час організації комунального управління воно органічно сполучається з управлінням суб'єктом федерації. Однак у ФРН наявні й інші міста - землі, до числа яких належать Гамбург, Бремен, а тому випадок поєднання комунального самоврядування з управлінням суб'єкта федерації не є поодиноким у контексті цієї країни.

Коли йдеться про Україну, різниця між міським самоврядуванням у столиці та в інших містах є доволі значною, адже в місті Київ функціонують i органи державної влади загальної компетенції, і органи місцевого самоврядування загальної компетенції.

Дослідники пишуть, що «основною функцією міста Києва як столиці є створення належних умов для діяльності в місті Президента України, Верховної Ради України, Кабінету Міністрів України, центральних органів державної влади, офіційних представництв іноземних держав і міжнародних організацій, установ і закладів науки, освіти, охорони здоров'я, культури і спорту, місцем розташування яких відповідно до законодавства визначено місто Київ, вирішення питань щодо розміщення центральних органів, які утворюються Президентом України, Верховною Радою України та Кабінетом Міністрів України, а також дипломатичних представництв, консульств іноземних держав та представництв міжнародних організацій в Україні» [11, с. 10]. Цим вони аргументують необхідність наявності в столиці України особливого (спеціального) статусу, коли йдеться про міське самоврядування.

Спеціальний статус, який має в Україні столиця, не свідчить про відсутність проблем у міському самоврядуванні Києва. Так, на думку А.Т. Назарка, «основною проблемою міст Києва та Севастополя як міст зі спеціальним статусом <...> є розподіл повноважень між органами міського самоврядування та органами державної виконавчої влади, адже в цих адміністративно-територіальних одиницях поєднано багато складників і не чітко розмежовано сфери компетенції та відповідальності» [12, с. 12]. Слід погодитися з висновком ученого. Тим більше, що він переконливо аргументує його, вказуючи, що «місцеве самоврядування в Києві та Севастополі не відповідає загальним вимогам, що властиві цьому інституту. Територіальні громади цих міст не мають мінімально встановлених прав щодо організаційної та матеріально-фінансової самостійності на рівні з іншими містами України; місцева рада позбавлена можливості створювати власні виконавчі органи, встановлювати систему та структуру виконавчих органів, затверджувати положення про відділи, управління та інші структурні підрозділи; порушується вся система взаємодії представницького та виконавчого органів місцевого самоврядування шляхом позбавлення підконтрольності, підзвітності та відповідальності другого першому; орган, що має здійснювати виконавчі функції, ставиться в рівне, а то й вище становище над представницьким органом» [13, с. 130]. Слід підкреслити, що ця думка не є новою в юридичній літературі, та більшість дослідників погоджуються з нею. 
Наприклад, характерні риси спеціального статусу міста Києва, з точки зору Ю. Скопненка, «суперечать концепції поділу влади, закладеній у Конституції України, а також принципам побудови відносин між органами місцевого самоврядування та місцевими державними адміністраціями, визначеними в Основному Законі України, Законі «Про місцеве самоврядування в Україні» та Законі «Про місцеві державні адміністрації» $[14$, с. 20].

Продовжуючи аргументацію сформульованої нами тези не аналізувати особливості міського самоуправління в столицях України та Сполученого Королівства, слід додати таке.

Зараз в Україні відбувається муніципальна реформа, яка стосується кожної територіальної громади, в тому числі й територіальних громад міст. Водночас вельми небагато уваги саме міському самоврядуванню приділяється в українській науковій літературі. Поки що окремої уваги заслуговували здебільшого Київ та Севастопіль як міста, що мають особливий статус. Що ж до інших українських міст, то незважаючи на наявність у кожного з них своїх культурних, історичних, інших характерних рис, проблем тощо, вони вкрай рідко привертають увагу фахівців з конституційного права. 3 цієї точки зору важливим практичним завданням $є$ подальше вдосконалення міського самоврядування, а важливим науковим завданням - теоретичне забезпечення цього процесу. Саме тому доцільним було б зосередити увагу на містах, які не мають особливого статусу, у т.ч. які не є столичними містами.

Ще одним аргументом на користь того, щоб не проводити порівняння самоуправління в місті Київ та в місті Лондон, є те, що в обох столицях воно є дволанковим (у Києві - міський рівень та рівень районів у місті, в Лондоні - Великий Лондон та його частини), однак якщо всі адміністративно-територіальні одиниці нижчого рівня в Києві є однаковими за назвою та статусом (райони у місті), то в Лондоні - ні. Великий Лондон поділяється на 32 лондонських бороу (borough), разом з якими існує і Ciтi (City of London Corporation). Порівняння буде утруднено необхідністю враховувати його особливості в Сіті.

Висновки. Варто відмітити, що Сіті є найбільш старою частиною Лондону та досі зберігає значну частину привілеїв, які для інших сіті були скасовані разом зі скасуванням їхніх хартій у XIX столітті.

До того ж завдяки збереженню традицій у міському самоврядуванні Лондону на території Сіті діє багато юридично значущих та церемоніальних звичаїв. Варто відмітити, що до цих звичаїв ставляться з повагою не тільки суб'єкти міського самоврядування, ретельно підтримуючи їхне існування, але й монарх Сполученого Королівства. Перспективи подальших досліджень полягають у введенні в доктринальний обіг фактичної та аналітичної інформації щодо самоврядування вардів та аналізу можливостей запозичення відповідного досвіду в Україні.

\section{Jimepamypa}

1. Нестерович В.Ф. Інституційне утвердження електронних петицій в Україні у контексті зарубіжного досвіду. Віче. 2015. № 22. С. 18-23.

2. Нестерович В.Ф. Конституційно-правова модернізація органів державної влади у рамках утвердження демократії участі в Україні. Науковий вісник Львівського державного університету внутрішніх справ. Серія юридична. 2016. № 1. С. 67-76.

3. Мішина Н.В. Актуальні проблеми викладання муніципального права в Україні. Наукові пращі НУ OЮA. 2016. T. 15. C. 161-167.

4. Мішина Н.В. Деякі особливості муніципального управління в Лондоні. Актуальні проблеми держави i права : Зб. наук. праць. Одеса : Юридична література, 2004. Вип. 22. С. 229-233.

5. Мішина Н.В. Територіальні громади та об’єднані територіальні громади в Україні. Наукові праці НУОЮА. 2019. Т. 24. С. 75-80.

6. Мішина Н.В. Муніципальне управління у Великому Лондоні. Наукові праиі Одеської нащіональної юридичної академії. Одеса : Юридична література, 2004. T. 3. С. 237-244.

7. Ежевский Д.О. Местное самоуправление в Соединенном Королевстве Великобритании и Северной Ирландии : автореф. дис. ... канд. юрид. наук. Москва, 2005. 198 с. С. 28.

8. Перфильева Н.С. Развитие местного самоуправления в Великобритании в конце XX - начале XXI века : автореф. дис. ... канд. юрид. наук. Москва, 2009. $21 \mathrm{c}$.

9. The City of London. Research and statistics FAQ. URL:https://www.cityoflondon.gov.uk/Corporation/ LGNL_Services/Business/Business_support_and advice/Economic information and analysis/ Research+and+statistics+FAQ.htm

10. City of London (Ward Elections) Act 2002. URL: https://www.legislation.gov.uk/ukla/2002/6/ contents/enacted

11. Федоренко В.Л. Столиця України - місто-герой Київ: поняття, адміністративно-територіальний устрій і функції (частина друга). Публічне право. 2013. № 1. C. $6-12$.

12. Назарко А.Т. Міське самоврядування в Україні : автореф. дис. ... канд. юрид. наук. Одеса, 2015. 26 с.

13. Назарко А.Т. Міське самоврядування в Україні : дис. ... канд. юрид. наук. Одеса, 2015. 224 с.

14. Скопненко Ю. Місцеве самоврядування в місті Києві: конституційні аспекти реформування. Віче. 2013. № 2. C. 19-22.

\section{Анотація}

Нестор В. Р. Столичне самоврядування у Сполученому Королівстві Великобританії і Північної Ірландіï. - Стаття.

Метою статті є огляд столичного самоврядування в Лондоні, а також формулювання висновків та пропозицій на підставі проведеного дослідження.

Лондон (Великий Јондон) вважається окремим регіоном. Це єдиний регіон Англії, який має свій індивідуальний адміністративно-територіальний поділ. Столичне самоврядування регламентується окремими нормативно-правовими актами, основним 3 яких 
є Акт про органи муніципального управління Великого Лондона 1999 року.

Великий Лондон у цілому (як один 3 дев'яти регіонів Англії) має такі органи місцевого самоврядування, як: Асамблея Лондона (представницький колегіальний орган, що складається 325 членів) та мер (обирається населенням). Слід звернути увагу на назву "Асамблея», а не «рада». В юридичній літературі часто висловлюється думка, що така назва споріднює цей представницький орган не з органами муніципального управління, а з парламентами історичних частин Сполученого Королівства Асамблеєю Уельсу, Асамблеєю Північної Ірландії.

У кожній з 33-х адміністративно-територіальних одиниць столиці Сполученого Королівства - у Сіті Лондон та у 32-х лондонських бургах - також функціонують муніципальні органи. Кожен з лондонських бургів має свою раду та мера (ця посадова особа в деяких бургах обирається муніципальною радою бурга, а в деяких бургах - населенням), а також виконавчий орган.

Сіті Лондон здійснює муніципальне управління зі збереженням традицій, до числа муніципальних органів належать Корпорація Сіті Лондон (обирається мешканцями та представниками бізнесу), Лорд-мер, два шерифи, Головний клерк, фрімени, суд олдерменів та інші церемоніальні органи та посадові особи. Дослідження структури та компетенції цих органів представляє здебільшого історичний інтерес. Сіті є найбільш старою частиною Лондону та досі зберігає значну частину привілеїв, які для інших сіті були скасовані разом зі скасуванням їхніх хартій у XIX столітті. До того ж завдяки збереженню традицій у міському самоврядуванні Лондону на території Сіті діє багато юридично значущих та церемоніальних звичаїв. Варто відмітити, що до цих звичаїв ставляться з повагою не тільки суб'єкти міського самоврядування, ретельно підтримуючи їх існування, але й монарх Сполученого Королівства.

Ключові слова: міське самоврядування, місцеве самоврядування, місто, міська територіальна громада, територіальна громада, публічна влада.

\section{Summary}

Nestor $V . R$. Capital self-government in the UK of Great Britain and Northern Ireland. - Article.

The purpose of the article is to review the capital's self-government in London, as well as to formulate conclusions and proposals based on the study.
London (Greater London) is considered a separate region. This is the only region of England that has its own, individual administrative-territorial division. Metropolitan self-government is regulated by separate legal acts, the main of which is the Greater London Authority Act 1999.

Greater London as a whole (as one of the nine regions of England) has the following local governments: the London Assembly (a representative collegial body of 25 members) and the mayor (elected by the people). It is necessary to pay attention to the name "Assembly", instead of "council". In the legal literature, it is often suggested that this name is related to this representative body not with the municipal authorities, but with the parliaments of the historical parts of the United Kingdom - the Assembly of Wales, the Assembly of Northern Ireland.

In each of the 33 administrative units of the capital of the United Kingdom - in the City of London and in 32 London boroughs - there are also municipal bodies. Each of the London boroughs has its own council and mayor (this official in some burghers is elected by the boroughs council, and in some boroughs by the population), as well as an executive body.

The City of London has a tradition of municipal governance, including the City of London Corporation (elected by residents and businesses), the Lord Mayor, two sheriffs, the Chief Clerk, Freemans, the Aldermen Court and other ceremonial bodies and officials. The study of the structure and competence of these bodies is mostly of historical interest. The City is the oldest part of London, and still retains much of the privileges that for other networks were abolished along with the abolition of their charters in the nineteenth century. In addition, thanks to the preservation of traditions in the city government of London, there are many legally significant and ceremonial customs in the City. It should be noted that these customs are respected not only by the subjects of municipal selfgovernment, carefully supporting their existence, but also by the monarch of the United Kingdom.

Key words: city government, local government, city, city territorial community, territorial community, public authority. 